\title{
Environmental factors influencing streamwater composition on sandstone (Vosges Mountains)
}

\author{
Théodora Nedeltcheva ${ }^{\mathrm{a}}$, Christian PIEDALlu ${ }^{\mathrm{b}}$, Jean-Claude GÉGOUT $^{\mathrm{b}}$, Jean-Pierre BoudoT ${ }^{\mathrm{c}}$, \\ Nicolas ANGELI ${ }^{\mathrm{a}}$, Etienne DAMBRINE ${ }^{\mathrm{a} *}$ \\ ${ }^{a}$ INRA, Centre de Nancy, Champenoux, 54280 Nancy, France

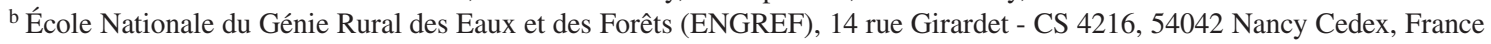 \\ ${ }^{c}$ CNRS, LIMOS UMR 7137, Université Henri Poincaré, Faculté des Sciences, Nancy, France
}

(Received 9 June 2005; accepted 29 November 2005)

\begin{abstract}
The influence of sandstone composition, precipitation, vegetation and relief on streamwater composition at base flow was studied in 95 forested catchments located in the sandstone part of the Vosges Mountains (N.E. France). Catchments lie on four main types of sandstone. Information was acquired for each catchment using a geographic information system (GIS) and spatially distributed databases. Sulphate concentration is mainly negatively correlated to the annual rainfall and positively to the relative area covered by conifers in the catchment. Nitrate is positively correlated to altitude. Sodium, $\mathrm{Cl}$ and $\mathrm{Si}$ concentrations are strongly inter-correlated and negatively related to the annual precipitation and the relative area of the conglomerate layer in the catchment. Calcium, Mg, ANC (Acid Neutralising Capacity) and $\mathrm{pH}$ are negatively correlated to precipitation, and positively correlated to the relative area of the sandstone layer containing dolomitic nodules. This study emphasizes the role of annual rainfall amounts in controlling stream chemistry at base flow.
\end{abstract}

streamwater / acidification / spatial analysis / Vosges / sandstone

Résumé - Facteurs environnementaux influençant la composition chimique des eaux sur substrats gréseux dans les Vosges. L'influence de la composition chimique des grès, des précipitations, de la végétation et du relief sur la composition chimique des ruisseaux en étiage a été étudiée dans 95 bassins versants des Vosges en utilisant un système d'information géographique (SIG) et des bases de données géo-référencées. La concentration en sulfates est corrélée négativement avec les précipitations moyennes annuelles et positivement avec la surface relative couverte par les résineux dans le bassin. Les nitrates sont positivement corrélés avec l'altitude. Le sodium, le chlorure et la silice sont fortement inter-corrélés et sont négativement liées aux précipitations et à la surface relative du conglomérat dans le bassin. Le calcium, le magnésium, l’ANC et pH sont négativement corrélés aux précipitations, et positivement corrélés avec la surface relative occupée par le grès de Senones, qui contient des nodules dolomitiques. L'étude souligne le rôle des précipitations annuelles sur la composition chimique des eaux en étiage.

chimie des eaux / acidification / analyse spatiale / Vosges / grès

\section{INTRODUCTION}

In the Vosges Mountains (north-eastern France), inventories of surface water acidity have shown that low ANC waters were located in two geological areas: granites and sandstones $[8,25,29,30]$. Studies of processes in a few forest plots or catchments carried out on both substrata have quantified sources and sinks of acidity and analyzed the dynamic of mineral elements in the ecosystem $[1,2,6,9,13,28]$. They showed that atmospheric deposition of acid and acidifying compounds were the main sources of acidity at high altitude in the northern part of the massif where the acid load was relatively high, whereas forest harvest contributed up to $50 \%$ to soil acidification in the south-western piedmont, relatively protected

\footnotetext{
*Corresponding author: dambrine@ nancy.inra.fr
}

from acid atmospheric deposition [13]. Environmental factors influencing streamwater acidity were analyzed by Thomas et al. [34] in 100 catchments of the sandstone area, using a large spatially distributed dataset describing environmental factors. Stream pH and ANC were successfully predicted using soil types, the catchment area and the relative surface and stratigraphic position of the different sandstone types in the catchment. The aim of the present work was to apply this spatial analysis to all mineral element concentrations in streams draining the sandstone area. For this purpose, we used a complementary set of complete water analyses from ninety five first-order streams collected at lowflow in 1995. The information on relief, rainfall, sandstone type and vegetation was compiled for each catchment using a GIS. Regression analyses were conducted to link stream water chemistry to sandstone types and environmental parameters. 


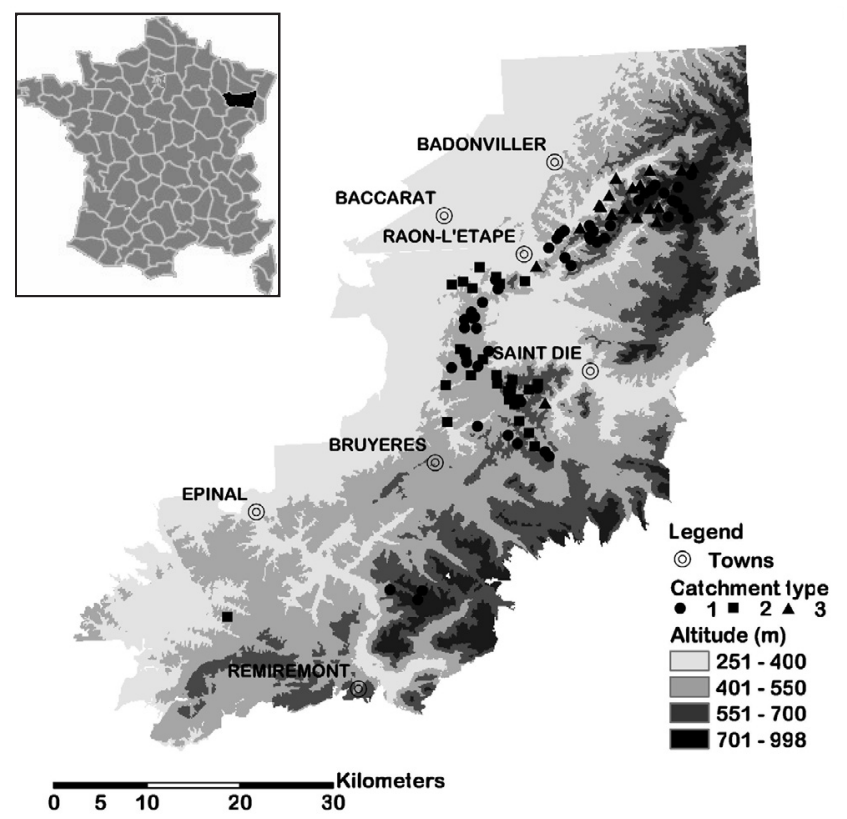

Figure 1. Map of the study area and position of the studied catchments.

\section{MATERIAL AND METHODS}

\subsection{Study area}

Ninety five mostly forested catchments covering a total area of 13808 ha were identified in the north-western part of the Vosges Mountains and range from $48^{\circ} 04^{\prime} 34.4^{\prime \prime}$ and $48^{\circ} 29^{\prime} 07.6^{\prime \prime}$ of latitude and $6^{\circ} 23^{\prime}$ 50.4" and $7^{\circ} 06^{\prime} 23.1^{\prime \prime}$ of longitude (Fig. 1). There are no houses or asphalted roads in these catchments. They range between 381 and $887 \mathrm{~m}$ a.s.l. The climate is cold oceanic with a continental influence. Mean annual temperature is $8{ }^{\circ} \mathrm{C}$ at $600 \mathrm{~m}$ a.s.l. and the temperature gradient is about $0.5^{\circ} \mathrm{C} / 100 \mathrm{~m}$. Mean annual rainfall varies between 1000 and $1600 \mathrm{~mm}$ in relation to altitude, and increases toward the south. Actual evapotranspiration (AET) ranges between 550 and $650 \mathrm{~mm}$ [4]. European beech (Fagus sylvatica) and Scots pine (Pinus sylvestris) are the major forest species at low altitude in the studied catchments, while Norway spruce (Picea abies) and white fir (Abies alba), often mixed with beech predominate at higher altitude. The percentage of non-forested areas is low but large clearings occur in the northern part of the area in relation to forest health disorders which occurred from 1985 onwards [35]. Annual deposition in bulk precipitation, calculated from a three years monitoring (1988-1991) at four sites, reached $0.20-0.29 \mathrm{kmol} \cdot \mathrm{ha}^{-1} \cdot \mathrm{yr}^{-1}$ of sulphur, 0.55$0.69 \mathrm{kmol} \cdot \mathrm{ha}^{-1} \cdot \mathrm{yr}^{-1}$ of nitrogen, $0.15-0.22 \mathrm{kmol} \cdot \mathrm{ha}^{-1} \cdot \mathrm{yr}^{-1}$ of sodium,

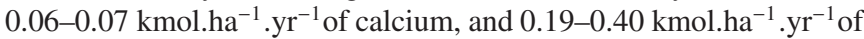
proton [14]. Mean annual concentrations in rain, except $\mathrm{pH}$, are negatively correlated to annual rainfall amount (Tab. I).

\subsection{Geological settings}

The basement of the North of the Vosges Mountains is composed of different sandstones and conglomerate dating from the Permian and Lower Trias (Bundsanstein). From the lower and older to the
Table I. Relations between mean annual concentrations in wet deposition $\left(\mu \mathrm{mol} . \mathrm{L}^{-1}\right)$ and precipitation amounts $(\mathrm{m})$ at four sites framing the study area (Dambrine et al. [14]).

\begin{tabular}{lcc}
\hline Element & \multicolumn{1}{c}{ Model } & $R^{2}$ \\
\hline $\mathrm{S}-\mathrm{SO}_{4}$ & $-7.0 \times$ PRECIPITATION +30.2 & 0.79 \\
$\mathrm{Na}$ & $-8.3 \times$ PRECIPITATION +25.6 & 0.46 \\
$\mathrm{Ca}$ & $-5.56 \times$ PRECIPITATION +12.2 & 0.79 \\
$\mathrm{~N}-\mathrm{NH}_{4}+\mathrm{N}^{-\mathrm{NO}_{3}}$ & $-32.0 \times$ PRECIPITATION +91.7 & 0.88 \\
\hline
\end{tabular}

Table II. Mean composition (\%) of the sandstone layers.

\begin{tabular}{lcccc}
\hline & $\begin{array}{c}\text { Senones } \\
\text { sandstone }\end{array}$ & $\begin{array}{c}\text { Vosgian } \\
\text { sandstone }\end{array}$ & Conglomerate & $\begin{array}{c}\text { Intermediate } \\
\text { sandstone }\end{array}$ \\
\hline $\mathrm{SiO} 2$ & 81.46 & 92.70 & 91.19 & 88.31 \\
$\mathrm{~A} 2 \mathrm{O} 3$ & 8.45 & 3.18 & 3.75 & 5.38 \\
$\mathrm{Fe} 2 \mathrm{O} 3$ & 1.46 & 0.46 & 0.69 & 0.97 \\
$\mathrm{FeO}$ & 0.11 & 0.36 & 0.53 & 0.31 \\
$\mathrm{MnO}$ & 0.06 & 0.00 & 0.02 & 0.11 \\
$\mathrm{MgO}$ & 0.33 & 0.00 & 0.66 & 0.32 \\
$\mathrm{CaO}$ & 0.47 & 0.37 & 0.00 & 0.19 \\
$\mathrm{Na} 2 \mathrm{O}$ & 0.25 & 0.10 & 0.20 & 0.20 \\
$\mathrm{~K} 2 \mathrm{O}$ & 5.30 & 1.55 & 1.30 & 2.85 \\
\hline
\end{tabular}

upper and younger level, the stratigraphic sequence is composed of Senones sandstone, Vosgian sandstone, Conglomerate and Intermediate sandstone (Tab. II).

The "Senones sandstone" is a soft layer composed of successive bands of quartzitic sandstone and clay beds enriched in micas. Orthosite is the most abundant feldspar. The contents of $\mathrm{SiO}_{2}$ and $\mathrm{K}_{2} \mathrm{O}$ are $81 \%$ and $5 \%$ respectively. Dolomite occurs as disseminated nodules only [26].

The "Vosgian sandstone" is a hard layer, mainly composed of coarse quartz sand (mean diameter $=0.5 \mathrm{~mm}$ ) coated by a dry siliceous cement. It contains very small amounts of $\mathrm{K}$-feldspars and muscovite. The rock content in $\mathrm{SiO}_{2}$ and $\mathrm{K}_{2} \mathrm{O}$ is $93 \%$ and $2 \%$ respectively. The mineral composition of the "Conglomerate" layer and the Vosgian sandstone are similar but the conglomerate layer contains a large amount of quartzite pebbles (mean diameter $=30 \mathrm{~mm}$ ) and forms the hardest parts of the tabular landscape.

The "Intermediate sandstone" lays over the conglomerate. It is less hard than the Vosgian sandstone. It is also composed of quartz sand (mean diameter $=0.24 \mathrm{~mm}$ ), but it is richer in K-feldspars and micas. The $\mathrm{SiO}_{2}$ and $\mathrm{K}_{2} \mathrm{O}$ contents are $88 \%$ and $3 \%$ respectively.

For the present study, catchments were subdivided in three main types on the basis of their chemical composition [26], (see Tab. II), and the position of the rich substrata in the catchment [34]:

Type I: Catchments entirely lying on Vosgian sandstone and conglomerate;

Type II: Catchments, whose upper part is lying on Intermediate sandstone, and whose lower part is based on conglomerate and Vosgian sandstone;

Type III: Catchments, whose upper part is lying on conglomerate and Vosgian sandstone, and whose lower part is lying on Senones sandstone. 
Soils are sandy, very acid and widely podzolised on Vosgian sandstone and conglomerate (type I catchments), except locally when colluvial deposits originating from intermediate sandstone occur [7]. Soils developed from conglomerate are especially shallow and rich in boulders. On Intermediate and Senones sandstones, clay release and weathering of K-feldspars and micas has led to the formation of cambisols of sandy to loamy-sand texture. Due to their high porosity these sandstone layers weather very deeply, over tenth of meters, forming a large water reservoir which supplies small cities in the surrounding.

\subsection{Methods}

Samples of water from streams were taken at the outlet of all catchments at low water flow, during three consecutive months with almost no rain, in the autumn of 1995 [18]. Both stream pH and ANC are maximal during this period. Water samples were filtered in the field with prerinsed cellulose nitrate Sartorius filters, $0.45 \mu \mathrm{m}$ pore diameter, stored at $4{ }^{\circ} \mathrm{C}$ and analyzed within a period of 5 days after collection. $\mathrm{pH}$ was determined in the laboratory using a combined glass electrode. Major cations and Si were measured using ICP-AES or flame absorption spectrophotometry $(\mathrm{K}, \mathrm{Na})$. Anions $\left(\mathrm{NO}_{3}, \mathrm{Cl}\right.$, $\mathrm{SO}_{4}$ ) were measured using ion chromatography. Dissolved organic carbon was measured with a Carlo Erba carbon analyzer. ANC was computed using streamwater composition data, taking into account the mean free charge of every cation and anion:

$$
\begin{aligned}
\operatorname{ANC}\left(\mu \text { eq. } .^{-1}\right)= & 2[\mathrm{Ca}]+2[\mathrm{Mg}]+[\mathrm{K}]+[\mathrm{NH} 4]+[\mathrm{Na}]+2[\mathrm{Al}] \\
& +2[\mathrm{Mn}]+2[\mathrm{Fe}]-2\left[\mathrm{SO}_{4}\right]-\left[\mathrm{NO}_{2}\right]-\left[\mathrm{NO}_{3}\right]-[\mathrm{Cl}] \\
& -[\mathrm{F}]-\left[\mathrm{PO}_{4}\right]-1.2[\text { fulvicacid }],
\end{aligned}
$$

where fulvic acid concentration was derived from the dissolved organic $\mathrm{C}$ concentration according to a triprotic analogue exhibiting a complexing site density of $5.42 \mathrm{mEq} \mathrm{H^{+ }} . \mathrm{g}^{-1}$ fulvate, and where the element concentrations are given in $\mu$ mole. $1^{-1}$.

Topographical information was extracted from a $50 \mathrm{~m} \times 50 \mathrm{~m}$ Digital Elevation Model (DEM) provided by the French National Geographic Institute (IGN). Using a Geographic Information System (Arc Info), a hydrologic algorithm allowed for the automatic delineation of catchments above the outlet points [20]. Morphometric parameters for each catchment were derived: minimal, maximal and mean altitudes, total area and average catchment slope. Annual precipitation has been calculated at the barycenter of each catchment using the AURELHY Model of Meteofrance at a scale of $1 \mathrm{~km}^{2}$ [4]. Vegetation maps including forest composition (coniferous, deciduous) and pasture at the forest parcel scale were used to compute the area-weighted mean vegetation cover of each catchment.

The spatial distribution of sandstone types was digitized over the entire study area from geology maps (1:50 000) [17]. For catchments extending on several sandstone types, we computed the relative surface of each bedrock substrata in the catchment. Soil type could not be used as an explanatory variable because data were available only in a small proportion of the study area.

The available information was compiled in a table in which each line is representative of a catchment and each column describes water chemistry, bedrock types, vegetation, or topography for this catchment.

Variance Analysis (ANOVA), multi-comparison testing of streamwater chemistry for the three types of catchment, and regression analyses were done with SAS routines. For each catchment type, we used the linear regression analyses to relate streamwater concentrations to the best correlated environmental variables. Only variables with a significant effect $(p<0.05)$ were selected. When the same variables were selected for all catchment types, generalised models were computed using the whole of the dataset.

\section{RESULTS}

The composition of stream water varies widely. Calcium ranges between 12 and $220 \mu \mathrm{mol} . \mathrm{L}^{-1} ; \mathrm{SO}_{4}{ }^{2-}$ between 25 and $150 \mu \mathrm{mol} . \mathrm{L}^{-1}$, and $\mathrm{pH}$ between 4.16 and 7.36. Dissolved organic carbon is below $80 \mu \mathrm{mol} . \mathrm{L}^{-1}$ for $67 \%$ of the catchments, but may exceptionally reach up to $1032 \mu \mathrm{mol} . \mathrm{L}^{-1}$. Using the average ion to $\mathrm{Cl}$ ratio in rain [14], we corrected base cation concentrations in streams from the proportion originating from rain [24]. This calculation illustrates a range of rain contribution to stream concentrations: 7 to $70 \%$ of stream Ca concentrations (average 31\%), 3 to $45 \%$ of stream Mg (average 17\%) and 61 to $107 \%$ of stream Na (average $83 \%$ ) and 48 to $273 \%$ of stream $\mathrm{S}$ concentrations (average $81 \%$ ). Values higher than $100 \%$ indicate temporal or permanent storage of rain inputs in the catchments.

In stream waters (non-corrected from rain inputs), several groups of ions are strongly inter-correlated (Tab. III). $\mathrm{Cl}$ is positively correlated to $\mathrm{Na}$ and $\mathrm{Si}$. $\mathrm{Mg}$ and $\mathrm{Ca}$ are positively intercorrelated. $\mathrm{pH}$ and $\mathrm{ANC}$ are positively correlated with $\mathrm{Ca}$ and $\mathrm{Mg}$, and negatively correlated with $\mathrm{Al}$. Si is positively correlated with $\mathrm{Na}$ and $\mathrm{K}$.

Rainfall and elevation, which are strongly intercorrelated, are negatively correlated to all streamwater concentrations, especially $\mathrm{Cl}, \mathrm{Na}, \mathrm{Si}$ and positively correlated to $\mathrm{Al}$ and $\mathrm{NO}_{3}$. $\mathrm{SO}_{4}$ concentrations are weakly negatively correlated to mean altitude and positively correlated to the percentage of coniferous cover. None of these variables are related to the catchment area.

A comparison of mean streamwater concentrations between catchment types is presented in Table IV. $\mathrm{pH}$ and ANC increase significantly from type I to type III catchments. Ca and $\mathrm{Mg}$ concentrations are significantly higher in type III catchments. Si concentrations are significantly higher in type II catchments. $\mathrm{NO}_{3}$ concentrations are significantly lower in type II catchments. Besides, mean rainfall, mean elevation and the percentage of conifers are lower for type II catchments.

Global models for $\mathrm{Na}, \mathrm{Cl}, \mathrm{SO}_{4}, \mathrm{NO}_{3}, \mathrm{~K}$ and $\mathrm{Si}$ concentrations were derived over all catchment types (Fig. 2). Sodium, $\mathrm{Cl}$ and $\mathrm{Si}$ are negatively correlated to annual precipitation and the percentage of the catchment area based on Conglomerate. $\mathrm{K}$ is negatively correlated to precipitation and positively to the mean slope of the catchment. Sulfate is negatively correlated to annual precipitation and positively to the percentage of conifers. Nitrate is best correlated to the altitude of the catchment.

Using the whole data set, global models for $\mathrm{Ca}, \mathrm{Mg}, \mathrm{pH}$ and ANC could not be derived. In this case we derived models for each catchment type, which are presented in Table V. In type I catchments, $\mathrm{Ca}$ and $\mathrm{Mg}$ are negatively correlated to annual precipitation and $\mathrm{Ca}$ is positively correlated to catchment 


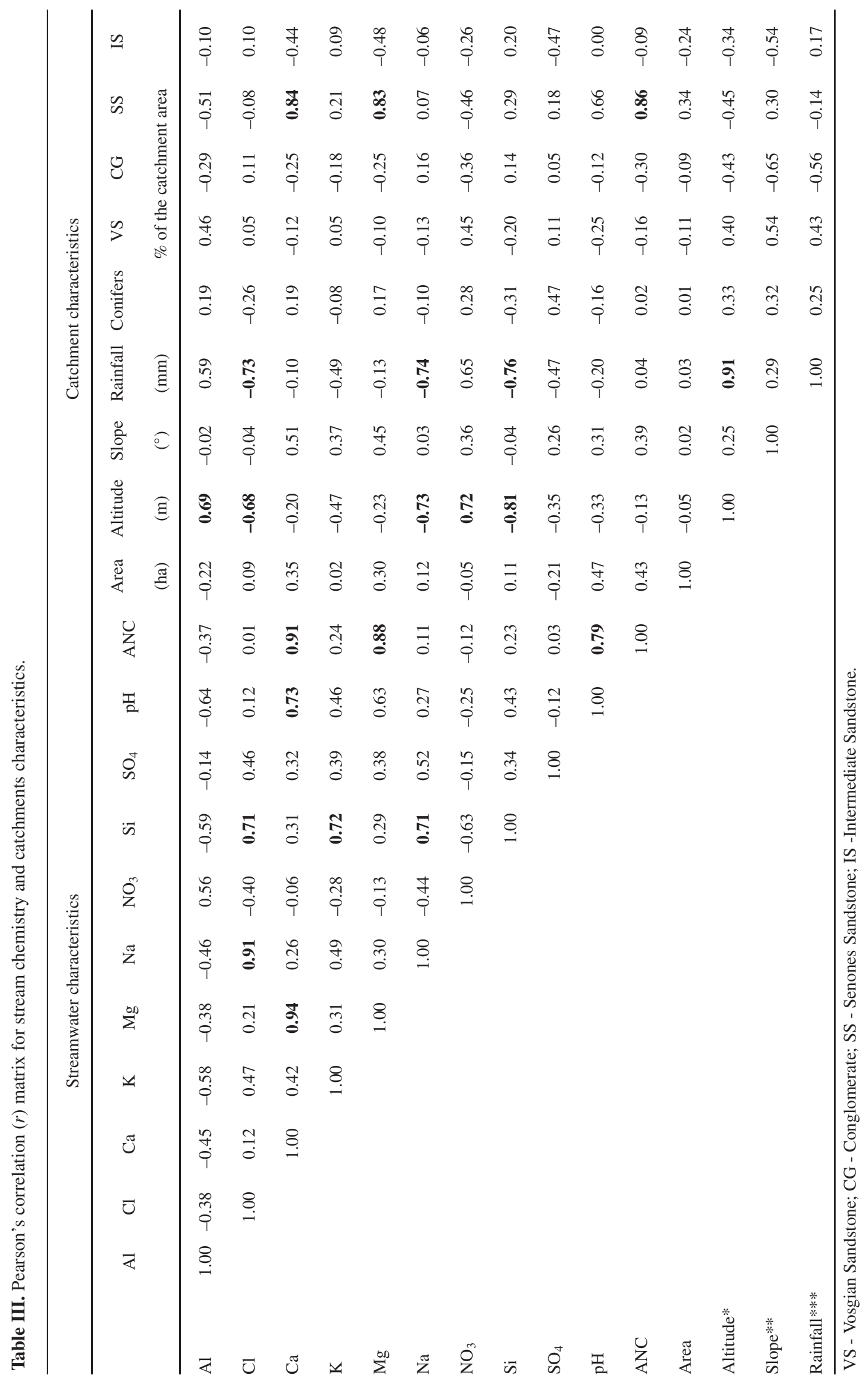


Table IV. Catchments characteristics and streamwater average concentrations and $\mathrm{pH}$ according to catchment type. Superscripts indicate significant differences between catchments types according to a Tukey test $(p<0.05)$ of log-transformed data (normality of populations).

\begin{tabular}{|c|c|c|c|c|c|c|c|c|c|c|c|c|c|c|c|}
\hline $\begin{array}{l}\text { Catchment } \\
\text { type }\end{array}$ & $\begin{array}{c}\text { Mean ann. } \\
\text { rainfall } \\
(\mathrm{mm})\end{array}$ & $\begin{array}{c}\text { Mean } \\
\text { elevation } \\
\text { (m) }\end{array}$ & $\begin{array}{c}\text { Mean } \\
\text { slope } \\
\left({ }^{\circ}\right)\end{array}$ & $\begin{array}{c}\text { Coniferous } \\
\text { coverage } \\
(\%)\end{array}$ & $\begin{array}{c}\text { ANC } \\
\left(\mu \text { eq. } .^{-1}\right)\end{array}$ & $\mathrm{pH}$ & $\mathrm{Ca}$ & $\mathrm{Mg}$ & K & $\mathrm{Na}$ & $\begin{array}{c}\mathrm{Si} \\
(\mu \mathrm{mol} .1\end{array}$ & $\begin{array}{l}\mathrm{SO}_{4} \\
1 \text { ) }\end{array}$ & $\mathrm{NO}_{3}$ & $\mathrm{Cl}$ & DOC \\
\hline I & $1281^{b}$ & $596^{\mathrm{b}}$ & $13.2^{\mathrm{a}}$ & $98^{\mathrm{b}}$ & $4^{\mathrm{a}}$ & $5.04^{\mathrm{a}}$ & $54^{\mathrm{a}}$ & $42^{\mathrm{a}}$ & $39^{a}$ & $57^{\mathrm{a}}$ & $104^{\mathrm{a}}$ & $94^{\mathrm{a}}$ & $55^{\mathrm{a}}$ & $61^{\mathrm{a}}$ & $107^{\mathrm{a}}$ \\
\hline II & $1124^{\mathrm{a}}$ & $491^{\mathrm{a}}$ & $11^{\mathrm{a}}$ & $82^{\mathrm{a}}$ & $32^{\mathrm{b}}$ & $5.59^{\mathrm{b}}$ & $58^{\mathrm{a}}$ & $40^{\mathrm{a}}$ & $44^{\mathrm{a}}$ & $64^{\mathrm{a}}$ & $124^{\mathrm{b}}$ & $84^{\mathrm{a}}$ & $38^{\mathrm{b}}$ & $69^{\mathrm{a}}$ & $56^{\mathrm{a}}$ \\
\hline III & $1365^{\mathrm{b}}$ & $632^{\mathrm{b}}$ & $19^{\mathrm{a}}$ & $94^{\mathrm{b}}$ & $205^{\mathrm{c}}$ & $6.23^{\mathrm{c}}$ & $106^{\mathrm{b}}$ & $87^{\mathrm{b}}$ & $43^{\mathrm{a}}$ & $56^{\mathrm{a}}$ & $110^{\mathrm{a}}$ & $86^{\mathrm{a}}$ & $56^{\mathrm{a}}$ & $60^{\mathrm{a}}$ & $69^{\mathrm{a}}$ \\
\hline
\end{tabular}
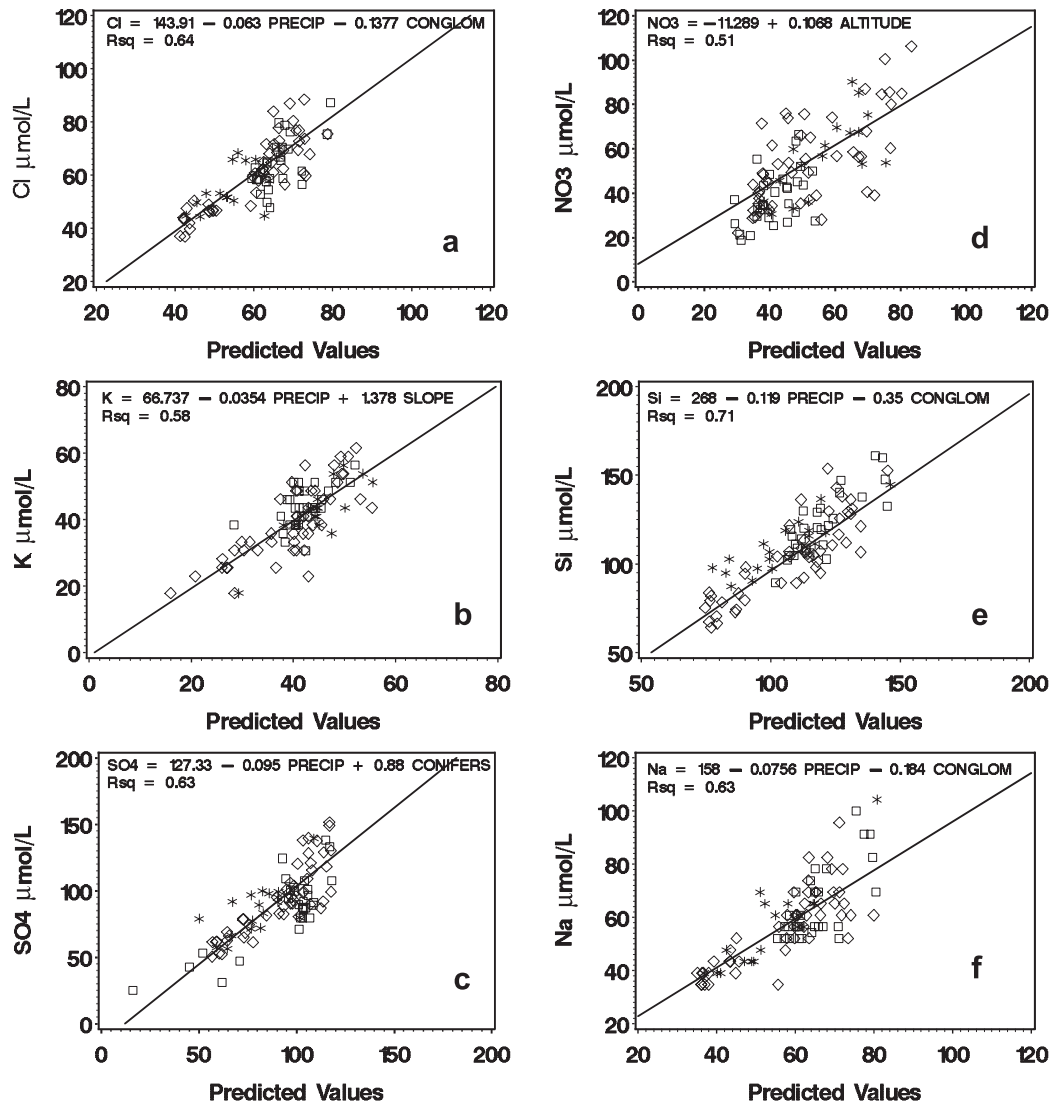

Figure 2. Relationships between measured and predicted values derived from linear regression analyses (PRECIP: precipitation in mm; CONGLOM: relative area of the catchment based on conglomerate; ALTITUDE in m; SLOPE in degree, CONIFERS: relative area in the catchment expressed in \%, covered by conifers: (a) $\mathrm{Cl}^{-}$; (b) $\mathrm{K}$; (c) $\mathrm{SO}_{4}^{2-}$; (d) $\mathrm{NO}_{3}^{-}$; (e) $\mathrm{Si}$ and (f) $\mathrm{Na}$ for the whole data set. Symbols: diamonds: type I catchments; squares: type II catchments; stars: type III catchments.

slope. In type II catchments, $\mathrm{Ca}$ is negatively correlated to the percentage of conglomerate and positively to the percentage of conifers. Magnesium is negatively correlated to precipitation and positively to the percentage of conifers. In type III catchments, $\mathrm{Ca}$ and $\mathrm{Mg}$ concentrations are positively related to the catchment area and the percentage of Senones sandstone, which contains dolomite nodules.

$\mathrm{pH}$ and ANC in streams draining catchment type I are negatively related to the mean annual precipitation and positively to catchment area. These parameters are mainly related to catchment area in type II catchments as well as with the relative area of Senones sandstone in type III catchments.

\section{DISCUSSION}

Our aim was not to draw budgets but to investigate the relationships between water composition and environmental factors. We have studied the chemistry of stream waters at lowflow regime in autumn. These waters drain four sandstone substrata mainly composed of quartzitic sands but differing by small, but increasing amounts of K-feldspar, muscovite and dolomite. These waters were collected in a geographically restricted area, but with a strong gradient of precipitation.

The overall streamwater mineralization is strongly negatively correlated to annual rainfall. Sulfate, $\mathrm{Na}$ and $\mathrm{Cl}$ originate 
Table V. Regression equations relating stream water $\mathrm{pH}$, ANC ( $\mu$ eq. $\left.\mathrm{L}^{-1}\right), \mathrm{Ca}$ and $\mathrm{Mg}\left(\mu \mathrm{mol} . \mathrm{L}^{-1}\right.$ ) to rainfall, catchment area, slope and Senones sandstone relative area for the three studied types of catchments.

\begin{tabular}{|c|c|c|c|c|c|c|c|}
\hline \multicolumn{2}{|l|}{ Catchment type I } & \multicolumn{3}{|l|}{ Catchment type II } & \multicolumn{3}{|l|}{ Catchment type III } \\
\hline Model & $\begin{array}{l}\text { Partial Rsq } \\
\text { Rsq }\end{array}$ & Model & $\begin{array}{c}\text { Partial } \\
\text { Rsq }\end{array}$ & Rsq & $\begin{array}{l}\text { Model } \\
\text { Rsq }\end{array}$ & $\begin{array}{c}\text { Partial } \\
\text { Rsq }\end{array}$ & Rsq \\
\hline $\mathrm{pH}=5.36-0.0011$ RAINFALL & $0.19 \quad 0.34$ & $\mathrm{pH}=4.08+0.788$ LOGAREA & 0.46 & $0.46 \mathrm{p}$ & +0.0148 SENONES & 0.58 & 0.58 \\
\hline+0.55 LOGAREA & 0.15 & & & & & & \\
\hline
\end{tabular}

$\begin{array}{ccccccccc}\text { ANC }=96.602-0.0734 \text { RAINFALL } & 0.31 & 0.31 \text { ANC }=-48.531+38.672 \text { LOGAREA } & 0.30 & 0.30 \text { ANC }=-327.8+6.37 \text { SENONES } & 0.68 & 0.81 \\ +170.6 \text { LOGAREA } & 0.13\end{array}$

mainly from the atmosphere. The concentration of these elements in rain is negatively correlated to annual rainfall and their concentration by evapotranspiration decreases when annual precipitation increases. These two factors explain the strong negative correlation with annual precipitation.

The soil and saprolite reserve in weatherable minerals is extremely low in type I catchments. As the availability of weatherable minerals is very limited, mineral elements such as $\mathrm{Ca}, \mathrm{Mg}, \mathrm{Na}$ and $\mathrm{K}$ released by weathering are diluted by the amount of drainage water that varies in parallel to rainfall. Another, complementary explanation is that soil impoverishment in mineral elements is related to the cumulated amount of rainfall.

$\mathrm{Ca}$ and $\mathrm{Mg}$ concentrations are mainly related to the relative area of the rich substratum (Senones) in type III catchments, which contains dolomite nodules. In type II catchments, $\mathrm{Ca}$ drainage may be lower because sulphate and nitrate concentrations below deciduous trees are generally lower [33] and $\mathrm{Ca}$ is generally correlated to anions concentrations.

Silica is negatively related to precipitation and to the relative area of conglomerate. The upper limit of Si concentration in streams is higher than the value corresponding to the equilibrium with quartz $\left(10^{-4}\right.$ mol.L $\left.\mathrm{L}^{-1}\right)$, and between the solubility values of biogenic opal from Abies alba and Fagus sylvatica [3]. The negative relation with precipitation is not a trivial result, because these waters have been collected at low flow, and therefore have spent a long time, probably several years or tenth of years, in the saprolite. This suggests that a greater proportion of $\mathrm{Si}$ is released from the soil, where water residence time is influenced by rainfall amount, than from the saprolite. An additional argument shows the role of the soil in supplying Si. The silica concentration in drainage solution from the E horizons of podzols developed from sandstone and in streamwater are in the same range $[9,23]$. The negative influence of the percentage of conglomerate may be related to the low depth and the high stoniness of the soils on this hard substratum [7], which reduce the mineral surfaces and the residence time.

As for $\mathrm{Si}$, stream potassium concentration is independent of catchment type and negatively correlated to precipitation. We did not find a simple explanation for the positive relation with catchment slope. The absence of relation between streamwater $\mathrm{K}$ concentration and rock $\mathrm{K}$ content may be related to the cycling of $\mathrm{K}$ by vegetation in the soil and along the stream, and trapping of the K released by K-feldspar weathering, by clays.

The strong relation between $\mathrm{Na}$, which originates mainly from the atmosphere, and $\mathrm{Si}$, which is only released by mineral weathering, shows that a parallel behaviour of ions should not be directly interpreted in terms of common origins. In this case both are strongly influenced by the water budget.

Thomas et al. [34] explained about $80 \%$ of the variability in stream $\mathrm{pH}$ and ANC by soil types and catchment area in streams draining catchment type I. This is better than the $34 \%$ of variability explained in this study using rainfall and catchment area. One may therefore question the effect of rainfall amount as a primary driver. We believe that dilution increases stream waters sensitivity to acidification and therefore that it is a rather logical parameter. But soil maps are more precise than geological maps to describe spatial variations of superficial layers in terms of buffering rates. In the other types of catchments, results of the two studies were comparable, confirming the role of the catchment area and the percentage of Senones sandstone on stream $\mathrm{pH}$ and ANC.

Other statistical analyses of large regional data sets have shown significant relationships between streamwater chemistry and some complex environmental factors, such as altitude 
and relief [24, 32], catchment size [37], glacial influence [10, 27], soil base saturation [5], land use [15] or some combination of these factors $[11,12,19,21,22,31,34]$. Surprisingly, the primary effect of precipitation amount was not often directly highlighted $[16,36]$.

\section{CONCLUSION}

The aim of this study was to analyse the spatial variability of streamwater composition at lowflow on sandstone. Our results show that between $30-60 \%$ of the variability of streamwater $\mathrm{pH}$ and between $60-70 \%$ of the variability of the mineral element concentration can be explained by three main factors: annual rainfall, bedrock composition and the area of the catchment. The influence of annual rainfall on water chemistry is highlighted because the bedrocks are homogenous and extremely poor in weatherable minerals. In this context, the presence of disseminated dolomite nodules in the bedrock influences strongly water alkalinity. The comparison with the work of Thomas et al. [34] confirms the relation between $\mathrm{pH}$ or ANC and catchment size, but also shows that detailed soil information is needed to predict accurately stream $\mathrm{pH}$ when the buffer capacity of the rock is very low.

Acknowledgements: The authors would like to thank Nadia Ignatova, Elisabeth Bienaimé, the Forest Department of INRA, the $\mathrm{ONF}$ and the Marie Curie network for their personal, technical and financial support to this work.

\section{REFERENCES}

[1] Ahmed M.D., Ranger J., The biogeochemical cycle in a healthy and highly productive Norway spruce (Picea abies) ecosystem in the Vosges (France), Can. J. For. Res. 24 (1994) 839-849.

[2] Ahmed M.D., Ranger J., Dambrine E., Bonneau M., Granier A., The current soil function of Norway spruce declining ecosystem assessed by the mass-balance technique: Effect of liming and fertilisation on the soil Nitrogen, For. Ecol. Manag. 60 (1993) 291-310.

[3] Bartoli F., Wilding L.P., Dissolution of biogenic opal as a function of its physical and chemical properties, Soil Sci. Soc. Am. J. 44 (1980) 873-878.

[4] Bénichou P., Le Breton O., Prise en compte de la topographie pour la cartographie des champs pluviométriques statistiques, Météorologie 7 (1987) 23-34.

[5] Billett M.F., Cresser M.S., Predicting stream water quality using catchment and soil chemical characteristics, Environ. Pollut. 77 (1992) 263-268.

[6] Bonneau M., Evolution of the mineral fertility of an acidic soil during a period of ten years in the Vosges mountains (France), Ann. For. Sci. 62 (2005) 253-260.

[7] Bonneau M., Faivre P., Gury M., Hétier J.M., Le Tacon F., Carte pédologique de France à 1/1000 000e, Saint-Dié, Notice explicative, (1978) 158 .

[8] Boudot J.-P., Guérold F., Rouiller J., Acidité des eaux dans les Vosges, Rapport de fin de contrat, 1996.

[9] Boudot J.-P., Maitat O., Merlet D., Rouiller J., Soil solutions and surface water analysis in two contrasted watersheds impacted by acid deposition, Vosges mountains, N.E. France: interpretation in term of Al impact and nutrient imbalance, Chemosphere 41 (2000) 1419-1429.
[10] Bricker O.P., Rice K.C., Acidic deposition to streams. A geology based method predicts their sensitivity, Environ. Sci. Technol. 23 (1989) 379-385.

[11] Cooper D.M., Helliwell R.C., Coull M.C., Predicting acid neutralizing capacity from landscape classification: application to Galloway, south-west Scotland, Hydrol. Process. 18 (2004) 455-471.

[12] Cresser M.S., Smart R., Billet M.F., Soulsby C., Neal C., Wade A., Langan S., Edwards A.C., Modelling water chemistry for a major Scottish river from catchment attributes, J. Appl. Ecol. 37 (2000) 171-184.

[13] Dambrine E., Bonneau M., Nys C., Ranger J., Gras F., Cycling and Budgets of Acidity and Nutrients in Norway Spruce Stands in Northeastern France and the Erzebirge, in: Landmann G., Bonneau M. (Eds.), Forest Decline and Air Pollution Effects in France, Springer, Berlin, Heidelberg, New York, 1995, pp. 233-258.

[14] Dambrine E., Ulrich E., Cénac N., Durand P., Gauquelin T., Mirabel P., Nys C., Probst A., Ranger J., Zéphoris M., Atmospheric deposition in France, in: Landmann G., Bonneau M. (Eds.), Forest Decline and Air Pollution Effects in France, Springer, Berlin, Heidelberg, New York, 1995, pp. 177-200.

[15] Evans C.D., Jenkins A., Wright R.F., Surface water acidification in the South Pennines I, Current status and spatial variability, Environ. Pollut. 109 (2000) 11-20.

[16] Gaillardet J., Dupré B., Louvat P., Allegre C.J., Global silicate weathering and $\mathrm{CO}_{2}$ consumption rates deduced from the chemistry of large rivers, Chem. Geol. 159 (1999) 3-30.

[17] Gégout J.-C., Piedallu C., Cartographie automatique des stations forestières du massif vosgien, Convention de recherche Ecofor/Engref $n^{\circ}$ 2000.43, 2002, 37.

[18] Guérold F., Boudot J.-P., Marlet D., Rouiller J., Vein D., Jacquemin G., Évaluation de l'état d'acidification des cours d'eau du département des Vosges, Rapport de fin d'étude, 1997, 69.

[19] Hornung M., Bull K.R., Cresser M., Ullyett J., Hall J., Hall J.R., Langan S., Loveland P.J., Wilson M.J., The sensitivity of surface waters of Great Britain to acidification predicted from catchment characteristics, Environ. Pollut. 87 (1995) 207-214.

[20] Jenson S.K., Domingue J.O., Extracting Topographic Structure from Digital Elevation Data for Geographic Information System Analysis, Photogramm. Eng. Remote Sensing 54 (1988) 1593 1600 .

[21] Kernan M.R., Allott T.E.H., Batterbee R.W., Predicting freshwater critical loads of acidification at the catchment scale: an empirical model, Water Air soil Pollut. 105 (1998) 31-41.

[22] Lacey G.C., Grayson R.B., Relating baseflow to catchment properties in south-eastern Australia, J. Hydrol. 204 (1998) 231-250.

[23] Maitat O., Spéciation de l'aluminium dans les sols forestiers acides et les eaux de surface soumis aux dépôts atmosphériques acides : significations pédogénétiques et implications toxicologiques, Thèse de doctorat de l'Université Nancy I, Nancy, 1998, 156 p.

[24] Meybeck M., Composition chimique des ruisseaux non pollués de France, Sci. Géol. Bull. 39 (1986) 3-77.

[25] Party J.P., Probst A., Dambrine E., Thomas A.L., Critical loads of acidity to France: sensitivity areas in the north-eastern France, Water Air Soil Pollut. 85 (1995) 2407-2412.

[26] Perriaux J., Contribution à la géologie des Vosges gréseuses, Mémoires du Service de la Carte Géologique d'Alsace et de Lorraine $n^{\circ} 18$ (1961) 236

[27] Phillips R.A., Relationship between glacial geology and streamwater chemistry in an area receiving acid deposition, J. Hydrol. 101 (1987) 263-273.

[28] Probst A., Dambrine E., Viville D., Fritz B., Influence of acid atmospheric inputs on surface water chemistry and mineral fluxes in a declining spruce stand within a small granitic catchment (Vosges massif, France) J. Hydrol. 116 (1990) 101-124. 
[29] Probst A., Massabuau J.C., Probst J.L., Fritz B., Acidification des eaux de surface sous l'influence des précipitations acides : rôle de la végétation et du substratum, conséquences pour les populations des truites. Le cas des ruisseaux des Vosges, C. R. Acad. Sci. 311 (1990) 405-411.

[30] Probst A., Probst J.L., Massabuau J.C., Fritz B., Surface water acidification in the Vosges Mountains: relation to bedrock and vegetation cover, in: Landmann G., Bonneau M. (Eds.), Forest decline and atmospheric deposition effects in the French mountains, Springer, Berlin, Heidelberg, New York, 1995, pp. 371-386.

[31] Rapp G.J., Liukonen B.W., Allert J.D., Sorensen J.A., Geologic and atmospheric input factors affecting watershed chemistry in upper Michigan, Environ. Geol. Water Sci. 9 (1987) 155-171.

[32] Rochelle B.P., Liff C.I., Campbell W.G., Cassell D.L., Church M.R., Nusz R.A., Regional relationships between geomorphic/hydrologic parameters and surface water chemistry relative to acidic deposition, J. Hydrol. 112 (1989) 103-120.
[33] Rothe A., Huber C., Kreutzer K., Weis W., Deposition and soil leaching in stands of Norway spruce and European beech: Results from the Höglwald research in comparison with other European case studies, Plant Soil 240 (2002) 33-45.

[34] Thomas A.L., Dambrine E., King D., Party J.P., Probst A., A spatial study of the relationships between streamwater acidity and geology, soils and relief (Vosges, northeastern France) J. Hydrol. 217 (1999) $35-45$.

[35] Thomas A.L., Gégout J.-C., Landmann G., Dambrine E., King D., Relation between ecological conditions and fir decline in a sandstone region of the Vosges mountains (northeastern France), Ann. For. Sci. 59 (2002) 265-273.

[36] White A.F., Blum A.E., Effects of climate on chemical weathering rates, Geochim. Cosmochim. Acta 599 (1995) 1729-1747.

[37] Wolock D.M., Fan J., Lawrence G.B., Effects of basin size on lowflow stream chemistry and subsurface contact time in the Neversink River watershed, Hydrol. Process. 11 (1997) 1273-1286. 